\title{
La Poesía de Enrique Bustamante y Ballivián.
}

Para Cristina Bustamante y Balliviáa.

En otro ensayo hemos reseñado la curva desigual de las generaciones finiseculares. Anotábamos como saliente característica, la ausencia de temperamentos literarios y cierto caudillismo fomentado por el único poeta bien dotado en esa época: José Santos Chocano. Pero si 1906 y 1908 , marcan tal vez la plenitud de Chocano con Alna América y Fiat $L u z, \sin$ disputa sus dibros definitivos e insuperados en su brega posterior-2-, eli año siguiente-rgog-señala, a nuestro criterio, la nueva etapa, o sea el inicio del tránsito de una poesía rotundamente "melopéyica", objetivista, de tono mayor, individualista, como la de Chocano, a las realizaciones más escuetamente artísticas, de tono menor, suljetivistas como las de José María Eguren, del González Prada de Exóticas, de José Gálvez, de Alberto Ureta, de Abraham Valdelomar, de César Atahualpa Rodriguez y Alcides Spelucín y aún del Vallejo de Los heraldos negros (I9I8), para no citar sino los más calificados, reconociendo en tanto, serias diferencias personales. Mas tratamos de anotar siempre tendencias mayores, dejando en segundo término el análisis de lo característico de cada individualidad. Podría hacerse así, un paréntesis que engloba la producción poética 
descle la aparición de la revista "Contemporáneos" en I909, hasta la publicación del primer libro de Vallejo (Los heraldos negros, de 1918) y del cuarto libro de Bustamante y Ballivián (Autóctonas, 1920), dejando aparte a Chocano cuya evolución había ya logrado la cúspide en Iøo8 (Fiat Lus) y cuya obra posterior, sostenemos, no acumula nuevos o más altos valores a los ya obtenidos.

A este paréntesis trazado provisionalmente quisiéramos denominarlo "el período de la transición". Por que es evidente el tránsito que entonces se opera del ejercicio poético con pocos aciertos estéticos de románticos y pos-románticos, a la severa hegemonía del buen gusto y de la sobria forma. Paso sensible de la elocuencia y el retoricismo pocas veces justificable, a la mesura y limpidez de las imágenes. Cambio indudable de una concepción prosaica y convencional de la creación poética, por un concepto superior de ella que tomaba ya sólo en cuenta las esencias estéticas y relegaba marginalmente a las solicitaciones y estímulos vulgares o inartísticos.

El carácter y la tónica vital de este período de tránsito encarnan en la obraly la figura literarias de Enrique Bustamante y Ballivián. Para evidenciar To $_{\text {que efectivamente }}$ significa la obra de este poeta, precisa referirse a los poetas más identificados con la tendencia que prevalecía anteriormente, eclosión de un pretendido "fin d'siecle" peruano y crisis de un romanticismo persistente y retrasado. Adrede deja de considerarse en esa tendencia anterior a Chocano, figura singular, sin conexión visible en el sentido de su obra-aunque sí en su persona-con grupo o movimiento alguno anterior o posterior. Chocano es un caso insólito dentro del proceso literario del Perú y aún en América misma. $\mathrm{Y}$ apartado Chocano, destacan como prototipos poéticos del pos-romanticismo-la etapa antecedente a la poesía de Bustamante-José Fiansón y Domingo Martínez Luján, Leoni- 
das Yerovi y Luis Fernán Cisneros. .Estudiar el carácter de la estación poética que estos vates resumen, urge para fijar el verdadero mérito de Bustamante y realizar su valuación crítica. El sensible contraste en el tono de sus respectivas obras, relieva necesariamente la poesía de Bustamante y Ballivián. Este no va a ser más el poeta alusivo de las dedicatorias, tampoco el improvisador o rimador de todo vulgar suceso del momento. Menos aún ha de incurrir en la frecuente herejía de poner la actividad poética al servicio de causas innobles o prosaicas.

\section{De LA INQUIETUd A LA CREACIÓN.}

Sino distinto tienen los dedicados a la cultura: los unos con el cometido de crear, los otros con la misión de despejar horizontes nebulosos, de abrir nuevas rutas, de señalar distintas orientaciones. Unas veces armonizan ambas capacidades en un sólo hombre, con singular vigor. En otras ocasiones, las actividades aparecen disociadas; el creador de un lado, el animador de otro. Por eso no procedería el paralelo entre la obra de José Santos Chocano o la de Eguren y la de Enrique Bustamante y Ballivian. Ea actitud y la obra de este último son únicas y singulares. Sus valores están más que en los versos mismos, más que en sus trabajos en prosa, en el espíritu que los producía, en la animación que los guiaba. La obra es apenas un diario de ruta útil para conocer las múltiples facetas de su cabal personalidad.

Su íntima y peculiar rebeldía espiritual repercute en la reiterada falta de continuidad formal en su obra. Su inquietud atenta contra la consecución de situaciones de vida fácil. Cuando su posición personal pudo haberle asegurado a perpetuidad el fácil acomodo burocrático en la capital, Bustamante inicia el viaje literario de las provincias con Daniel Alomía Robles, igual que antes o después Valdelomar lo había ensayado. Su actitud no era la complementaria a la 
vulgar bohemia de Martínez Luján o Fiansón, meros trasnochadores en Lima y alrededores. Bustamante había ya superado esa etapa.

Ello es síntoma de su extraña inquietud de hombre y de poeta, fácil de morigerarse mas nó de desaparecer cuando, por su cultura y su peculiar delicadeza personal, fué llamado a las filas de la diplomacia. Entonces empeñóse en transformar la fría adustez del cargo en una cálida central de vinculaciones literarias, of reciendo a los extraños círculos, fueran bolivianos o brasileños o uruguayos, aquello desconocido que el Perú tenía en su cultura o trayendo al Perú el conocimiento de realidades literarias casi desconocidas, como en esas memorables traducciones suyas de Poctas brasileros (Río de Janeiro, I922) o 9 poetas nucvos del Brasil, (Lima, I930). Ese concepto natural, espontáneo y culto, tenía él de la diplomacia y en ello coincide y antecede a la sugestiva y múltiple prestancia cultural de un Alfonso Reyes, poeta en la más alta acepción, prosador incomparable y embajador antes en Río, y en Buenos Aires ahora.

Juzguemos a este hombre de inquietud que es Bustamante, en sí mismo, que una comparación con otros grandes creadores como Chocano o Egturen, que se redujera simplemente al cotejo de obras, en plan de fijar aciertos o desaciertos aquí o allá, nos daría deformada noción de la significativa actitud y posición de Bustamante y confusa impresión de sus valores dentro del proceso de la literatura peruana, especialmente dentro de la poesía de los últimos tiempos.

El PALADÍN DE LA POESÍA.

Los comienzos de Bustamante y Ballivián, están señalados más que por la publicación de sus primeros poemas, por la aparición de su revista "Contemporáneos" en 1909,cuya dirección comparte con Julio A. Hernández-, de tanta 
trascendencia y decisiva importancia en la evolución de nuestra poesía moderna.

Poco antes, sin embargo,-en un interesante semanario de distrito, "Balnearios", editado en Barranco-habían aparecido sus "Jardines", crepusculares y decadentistas, próximos a los líricos deslaves de una época de Yerovi y a la mu-. sa grácil aunque indolente de Luis Fernán Cisneros. De esta iniciación proclive aún al romanticismo, antes que al modernismo, el poeta no quiso acordarse más. A pesar de que desde entonces-I908-el libro quedó estructurado-Jardines_, empeñóse el autor en mantenerlo inédito, sin referirse a él en oportunidad alguna. Probablemente vislumbró una dirección equivocada que, con toda videncia y acierto, rectificó en Elogios y en sus obras posteriores.

"Contemporáneos", significó la ruptura algo velada con las tendencias poéticas anteriores, (Fiansón, Yerovi, Cisneros, etc.) e, incluso, con la que implicaba Chocano. Sus páginas traían los brotes literarios de otra generación con un concepto más estrictamente estético y más artísticamente ortodojo que el anterior. Surgía en sus números quincenales, un nuevo grupo, distinto y juvenil, original y vigoroso, dueno, tanto de un moderno concepto del arte, como de una nueva concepción de la vida. Asomaron a esas páginas, desde los primeros números, los nombres de Manuel González Prada, de José María Eguren, de José Gálvez, de Alberto Ureta, de Abraham Valdelomar, ya entonces poeta y prosador y olvidada algo su trayectoria de dibujante travieso y de retratista intuitivo. (La iconografía de Bustamante le debe, tanto como la de Eguren y Gibson, una de sus mejores interpretaciones al carbón). Se iniciaba ya desde el primer número, la retardada revelación de un gran poeta, cuyos primeros versos habían pasado inadvertidos diez años antes en "Lima Ilustrado": era José María Eguren, alentada su peculiar modestia al par que con el cálido estímulo de González Prada, con la voz animosa, promisora y reconfortan- 
te de Enrique Bustamante y Ballivián. Se iniciaba la cruzada contra la incomprensión y el tradicionalismo literario imperantes, de la cual era el segundo un esforzado adalid. "Contemporáneos" va a preparar así el ambiente para las próximas ediciones de Simbólicas (I9I I) de Eguren y Exóticas (I9II) de González Prada.

Por la calidad de la colaboración histórica y filosófica, "Contemporáneos" toma la estructura de una revista de humanidades. Incursionó por ella alguna vez la rutina universitaria, más la revista tenía su propio "clima", a cubierto de interferencias. $Y$ es síntoma notable que Prada se sintiera cómodo dentro de ella y fuera extrañamente pródigo en sus colaboraciones. A su vera, surgen a la vez que los poetas, los ensayistas o prosadores como Pedro Zulen, Juan Bautista de Lavalle, Raymundo Morales, Joaquín Capelo, Emilio Huidobro, Oscar Miró Quesada, Jorge Miota, Carlos Wiesse, Felipe Barreda, Pedro Irigoyen, Fernando Tola, Toribio Alayza. Y figuran más nombres aún que, como los de Diómedes Arias Schreiber y Hernán Bellido, trocaron pronto la literatura por otras actividades menos ingratas.

Presidió siempré la revista da misma amplísima cordialiclad que caracterizó a su director descle entonces. Se percibe pronto la ausencia de limitaciones y de egoísmos de grupo, pero sin afectar su coherencia intelectual de órgano de generación. Ninguna traba para acoger a los últimos o a los penúltimos-en sus páginas escriben también alguna vez Fiansón y Beingolea,-pero sin desmedro del señorío de la selección, del buen gusto, de un nuevo sentido de la belleza poética. Estas nuevas rutas había señalado el ánima culta y entusiasta de Enrique Bustamante y Ballivián, de quien apenas se conocía algunos poemas de Elogios y cuya palabra inteligente y pensamiento firme daban ya personalidad a una revista y contribuirían a señalar el rumbo a una generación. En los diez únicos números publicados de abril a setiembre de 1909, este quincenario cumplió su come- 
tido de innegable trascendencia en la historia de poesía peruana.

Su modernismo: SEnda de Rubín.

Pocos meses después de la experiencia de "Contemporáneos", corriendo el año I9Io, aparece el primer libro de Iustamante: Elogios (Lima, Talleres Tip. de la Revista, IgIO). Cuanto se ha dicho de este libro, ha sido meramente la frase de compromiso, pero casi ningún juicio de rigor crítico. No obstante, Elogios constituye-con Autóctonas del mismo autor-uno de los libros más perdurables de la moderna poesía del Perú. La obra vale más por su significado, por su tono, por su prestancia y ritmo elegante y discreto, que por la inspiración misma y la hondura y trascendencia del pensamiento. Elogios es en poesía, lo que aquella novela epistolar Cartas a una turista del nunca bien justipreciado Enrique A. Carrillo, es en la prosa.

¿El subtítulo que el libro ostenta de "poemas paganos y místicos" quiere explicar ya algo el carácter de esas composiciones. Era la época en que Darío había definido y plasmado en poesía la extraña mezcla de religiosidad externa, ostentosa, individualisima y heterodoxa, y de paganismo violento. Bustamante incurre en esta dualidad-el libro recoge un elogio a Cristo al lado del que exalta a la carne y a la lujuria-aunque sin el clesbordamiento peculiar en el autor de "Ite misa est". $\mathrm{Ni}$ afección por la liturgia deslumbrante, ni arrebato por el mito pagano y sí equilibrada y voluntariosa poesía ideológica ésta del Bustamante de Elogios Los críticos han querido ver la semilla del simbolismo germinando aquí, mas si el examen es minucioso, apenas ha de hallarse menudos aportes simbolistas como no sea la insistencia victoriosa-y entonces todavía desconcertante-del verso libre. $\mathrm{Y}$ así, unas veces apartado de Rubén, haciendo "modernismo" a su manera-y de muy original maneray otras veces a su vera. 
Siguiendo la misma ruta anotada de Dario, Bustamante y Ballivián escribe en I9I2, tn libro que permanece hasta hoy inédito: Minuctos y Tapices, vinculaclo a la tendencia de Elogios. Este libro inédito es utilisimo para fijar mejor la calidad de la tendencia modernista de Bustamante, aparte de su nérito intrinseco. Todavia en Elogios sit entusiasmo modernista no lo había arrastrado a los ensayos de musicismo verleniano. El ninueto y $\mathrm{cl}$ tapiz evocan un siglo dieciocho de fastuosidades versallescas, de festiva exaltación y de voluptuosa laxitud a lo Wattean.

\section{En la línea galante de la reverencia, el pic de adelante no sé qué insintuo. Tus ojos anbigios, tu boca fragante, decian que sí, diciendo que nó. ( I)}

Queda la duda de si Bustamante fué captado por la sugerente musicalidad de Rubén y su aristocraticismo cortesano o si ambos dos derivaban del verbo múltiple y avasallador del Pablo Verlaine de Fiestas galantes. 'Típicas imágenes las de estos versos-los del autor de "Era un aire sulve...." y los del de Minuctos y tapices-de carácter pictorico, que son clirectas reminiscencias de Wattean, de Fragonard, de Boucher, pintores cortesanos del siglo XVIII. El sutil crítico argentino Arturo Marasso ha señalado en tuln definitivo libro, el origen y las fuentes de ese aspecto de la obra de Rubén Dario (2). En todo caso, Bustamante era permeable, directa e indirectamente, en el asunto dieciochesco y en la delicada musicalidad, a la influencia--entonces casi invencible-del autor de Sagesse. Mientras que de otro lado, en esos momentos era cuando Rubén ejercía con más (ito, 1912).

(1) Do "Minueto VI" (Escorzo Watteau), on Munetos $g$ tapiceg, ino-

(2) Arturo Marasso, Rubén Dario $¥$ в c creación pó́tica, La Plata, 1934. 
arresto su magisterio. Al auge anterior provocado por la aparición de stus primeras obras, seguia ahora su nueva actualización, con la bellísina revista "Mundial", dirigida en Paris por el propio Dario de I9I I a I9I4.

También Bustamante acogía la nota renacentista y meridional y se entregaba a la lírica sugestión de los canales renecianos, tan arraigados a la temática literaria de esa época:
Gotidolero, marinero de las naves del amor, en cuantas noches de luna has paseado la fortuna de un incógnito señor; rompiendo cuando bogabas el agua de los canales, despertando, si cantabas, tu cantar
a los tranquilos cristales, de su ensueño secular.

Gondolero, boga y canta, ruede el agua en los extremos de tus remos, y la voz en tu garganta diga ritmos, gondolevo.

A esta misma etapa corresponde un libro suyo publicado, con mucho retraso, catorce años después: Odas aulgares (Editorial La Cruz del Sur.-Montevideo, I927). Podria pensarse que los "coloquios" aquí contenidos, de las bestias, los hombres y la noche, algín vínculo o nexo presen-

(3) "Gondellied", en Minzetos y tapices, inédito, (1912). 


\section{$-88-$}

tan con el rubendariano "Coloquio de los centauros" Más en Bustamante se perfilaba antes que el discurrir ideológico de Darío, la plasticidad descriptiva de grandes visiones:

Bueyes augustos que coronados de flores asistísteis al cortejo de las fiestas paganas, en que reían los amores alocados, bajo el reflejo del sol, y que manchásteis de tonos granas con vuestra sangre fecunda en holocaustos las aras, y en las hogueras ardisteis en los faustos del fuego crepitante y purificador.

Bueyes hieráticos de los cultos del Asia, con blancas estrellas en la frente

y gesto dominador;

buey que cristianamente

lleno de mística gracia, viste nacer a Jesúis;

$y$, vosotros, los más grandes y sagrados,

los que váis mansamente uncidos a los arados

y lleváis la energía en el testuz, los que abrís a las germinadoras potencias los vientres de la tierra, y mugís alegremente en las auroras, ante la alegría que encierra la luz del día, llena de fuerzas productoras, $y$ en las horas crepusculares, con misteriosa unción, 
hacéis de todos los campos altares

para una sencilla y solemne religión.

\section{D'ANNUNZIANISMo FUgAZ Y PARNASIANISMO PRósPERo.}

Pronto se señala el tránsito de la influencia modernista o verleniana a la del d'annunzianismo que en Bustamante habia de señalarse sobre todo en la prosa. "Divagación ideológica" subtitula Bustamante a su libro La evocadora (Lima, Talleres tipográficos de la Penitenciaría, r913) Prosa ésta decadentista y crepuscular, con imágenes frecuentemente gaseosas y frágiles. Tonos grises en que un pensamiento estructural cedía el paso a un desordenado hilván de fragmentos de personal filosofía idealista, Mejor que cualquier consideración marginal, hablan de sus lecturas de entonces, de su literatura predilecta y señalan el ritmo de su prosa, estos párrafos sobre el paisaje, extraídos de un capítulo de La evocadora: "Es en el último siglo cuando el paisaje llega a tener una representación espiritual, alta y verdadera, de alma y de yida, gculta y simbólica, pero en el camino del misterio y de lo trascendental so, iLos paisajes rítmicos de Laforgue ? i Verlaine, con la melancolía gris de los parques ingleses en los que Canta la lluvia para su corazón que se hastia! El paísaje de lo desconocido en Maeterlinck, con las arboledas y los estanques en la angustia del trágico cotidiano que se cierne sobre sus vidas, en la claridad de los dias y en la nocturna quietud de la sombra. Y D'Annunzio con la sequedad de los campos áridos, estremecidos por el ambiente de la Cita morta, y los paisajes espirituales en cue las Virgenes de las rocas ponen la fatalidad de su misterio en la solemnidad suntuosa de las praderas romanas. i Violante, Masimilia, Anatolia! ¿Los disticos

(4) "Los bueyes", en Oadas vulgares, Moutevideo, 1987. 
en los plintos marmóreos y los faunos y silenos bajo la pátina de los musgos ancestrales."

Los ecos de El Fuego y más aún, los de Las Virgenes de las rocas no embargan por mucho tiempo la extraña inquietud espiritual de Bustamante. Pronto recoge otros estímulos y mejores notas como tal vez las apagadas y silentes del simbolista francés Rodenbach, y hace su asimilación menos violenta. Habría que disentir con más de un crítico que ha encontradc la huella de Maeterlinck. Ni la bruma del misterio, ni el color de lo ultra-humano asoman en las páginas de esta época. Vienen así las suaves cadencias de Arias de silencio (Lima, I9I5), libro coincidente con su empresa editorial de "Cultura", revista con la que el poeta pretende restaurar la vigorosa existencia de "Contemporáneos".

La angustia, la melancolía, la fatalidad y el ritmo meridional d'annunziano desembócan en un parnasianismo de radiante objetividad a lo Herrera y Reissig, dos años después de la aparición de La evocadora. Bustamante caía en el Parnaso y no en un más definido simbolismo. Mejor que así fuera, porque por esa ruta de una poesía objetiva, realista, hasta cierto punto, plástica, había de robustecerse años más tarde esa tendencia de sus poemas posteriores de lograr la captación del motivo nacional, indígena o americano, patente en Autóctonas y en Junin: realismo poético, que va a ser integrado luego con la aproximación a los regionalistas braliños que él traduce, de firme contenido terrígena: literatura de América, arraigo a la tierra e identificación con sus problemas vitales.

Todavía en I9I5, Bustamante hacía, pues, sus primeras armas parnasianas en Arias de silencio (Lima, I915). Es perceptible aquí cierta aproximación al Herrera y Reissig de Los parques abandonados y Los ćxtasis de la montaña:

Había un alma en el silencio de ese jardín abandonado. 
Un banco sileno

de mármol reía.

Enigmática risa. Tiempos

pasados sileno añoraba.

El mármol sufriendo

recuerda el pasado.

Las ninfas languidecieron,

-nostalgias de los surtidores-

. su perfume incierto

por el jardín vuela.

Había tranquilos ensueños

en las galerías de mi alma.

Estaba muriendo

una tarde clara.

Un paréntesis se abre luego en la producción de Bustamante, absorbido largos meses por la dura experiencia periodística; el paréntesis preciso para producir la obra definitiva, descle I9I 5 hasta después de 1918 , época en que enpieza a escribir los poemas de Autóctonas.

En otras páginas del mismo libro, Bustamante tiene apuntes de gran delicadeza:

Una voz vestida de sombra

ha veniclo a decirme todo

al amor de la hora

negra en que soniando vivo................

19r 5 , es un año de gran actividad literaria: además de su libro Arias de silencio, Bustamante inicia la publicación de su nueva revista "Cultura", intento suyo de revivir "Con-

(5) De Arias de silencio, Lima, 1910 . 
temporáneos". Su vida fuć indudablemente breve, pero no tan corta que sólo llegaran a aparecer "el primer y único número" como equivocadamente afirma Mariátegui. Vieron la luz tres números mensuales de junio a agosto. Pero evidentemente' "da la impresión de una revista ecléctica, menos representativa que "Contemporáneos". (6)

\section{IMPRESIONISMO REGIONALISTA.}

Por esos años, el periodismo sustraerá al poeta y éste deja, al parecer, la creación en suspenso. "El Perú", que dirigieron sucesivamente Luis Fernán Cisneros y Víctor $M$. Maúrtua, le abre sus páginas para la brega diaria. Y llega I917, el año en que Bustamante decide el abandono de la capital y el viaje por las provincias al extranjero: el norte del Perú y luego Ecuador, Panamá y Cuba. Lo acompañará un artista tan animoso como él: Daniel Alomía Robles, músico integral y arquetipo de peruanismo auténtico. El dinero escaseaba, pero la voluntad de crear y de captar sobraba. Hubo en el itinerario provinciano de Bustamante, la actitud deportiva, acorde conlla época, aventurera más nó bohemia, de quien afronta el viaje conlal únicavespectativa económica de lo que producirá el trabajo artístico: hacer la vida con el arte y el arte tomado con actividad casi de profesional y no de diletante. Recorrido éste de captación nacional-haciendo música y recitando poesía-de búsqueda inquieta de panoramas nuevos, con cierta vaga semejanza con el emprendido hace pocos años por el poeta español Federico García Lorca, a través de los pueblos españoles. De esa aguda experiencia peruanista, iban a nacer los poemas regionales de Autóctonas ( $\mathrm{La} \mathrm{Paz}, \mathrm{1920}$ ).

Ahora su poesía-a pesar de que aún no se encuentra

(6) V. José Carlos Mariátegui, 7 ensayos de interpretación de la realidad peruana, cap. "El proceso de la literatura, p. 217. Lima, Imp. Miner-
va, ?928. 
despojada del parnasianismo-, ha roto evidentemente el vínculo con Rubén Darío. Más se acercan a Chocano esos pocmas de evocación americanista que cantan el cóndor, el puma, el lago, paisaje y habitante de este continente.

Las llamas altaneras, de grácil cuello fino y lento andar, parecen antiguas viajeras venidas desde el fondo del Destino.... como alma y carne del paisaje andino, graves y solemnes se les ve pasar.

¡Oh, mañana

serrana

que nacida en el seno fecundo de la aurora, tienes tan triste y lejana poesía evocadora!

¡Cómo cantan tus ámbitos todos el augusto himno matinal!

Ante el paisaje mutestra Bistanante tuna típica reacción impresionista. Su descripcionismo está limitado por su espíritu siempre fecundo en el comentario estético. „En ello hay ya superación del impasible espectar la belleza objetiva. Su dinámica percepción deja siempre un trazo personal en sus versiones. Obsérvese su diseño del cóndor:

Señor de la selva, la cumbre y el llano

fiero puma

de garra firme y mirar lejano

que acecha el blancor de espuma

de los corderos,

(7) De "Mañana campesina" en Autóctonas, La Paz. 1920. 
las áureas sedas de las alpacas y la carne roja de los terneros que como a futuros toros, miran las vacas ( 8 )

\section{UN ATISBO EXPRESIONISTA.}

Autóctonas es un libro múltiple en sus aspectos. Recoge, al mismo tiempo que algunos poemas de sus pasadas tendencias parnasiana y modernista, las nuevas creaciones de su experiencia terrígena y las vibraciones de la inquietud colectiva del momento. Parece, por su multiplicidad de notas, el libro-síntesis de la inquietud de Bustamante, el que resume las más variadas facetas de su vigorosa personalidad, el que fija su calidad de animador y captador de tendencias nuevas. $\mathrm{Su}$ selección espiritual y su búsqueda del placer estético, no le impidió recoger las voces del dolor colectivo y hacerse eco de un férvido humanitarismo:

¿Y otro año! La tristeza del campo,

la angustia de la ciudad

y aquella pena mansa y conforme

de vivir, parece poco, los hombres quieren más :

Se agrupan en legiones fantásticas,

y en torbellino, unos contra otros van;

los que no mueren se manchan de sangre, insultan los que no pueden matar;

y todo es ceguera y odio

para la humanidad.

$\mathrm{Y}$ siguen las muchedumbres

con su gesto fatal

caminando en el sendero

sin saber a dónde van,

(8) "El puma" en Autóctonas, La Paz. 1920. 
oculto el sentimiento de protesta, en el rostro un gesto de conformidad.

Luchan, tienen las manos tintas en sangre.

ciega su mitada está,

y no saben los vivos ni los muertos

a clonde los lleva la fatalidad. (9)

Este poema lo identifica ya con otra sensibilidad. Hasta podria encontrarse la analogía con alguna cercana muestra de poesia expresionista alemana. Ningún calco habría; la coincidencia es plena y vital como en los posteriores indigenistas del Perú. ( IO).

La fuerza extraña a toda su obra anterior que brota de ese poenia, lo clelata ya como un creador desligado de la elocuencia y el verbalismo modernista. Será ésta la actitud ante la vida que ha de perdurar en él hasta su muerte. Simple, descarnado, sin palabras pomposas, anti-retórico, se inicia así el futuro autor de Anti-pocmas y de Junin. Los viajes han de brinclarle la brisa fresca que exige toda renovación y la fuga de antiguos gérmenes de juego verbal enfermizo.

\section{EL POETA DE NutSTRO TIEMPo,elli Conversom}

El poeta viajará intensamente por espacio de más de un decenio. El Perú antes y después, y entre tanto, Bolivia, Argentina, Brasil, U1'uguay. $Y$ libros nuevos que va dejando en cada capital. En La Paz: Autóctonas, (1920) ; en Río de Janeiro, dos: las traducciones de Poetas brasileros, (1922) y la Epopeia do tropico (1926). Odas unlgares (1927 en Montevideo y Anti-pocmas ( 1927 ) en la capital argentina; ediciones todas que son signos de su alma de viajero exquisito y de diplomático de la inteligencia.

(9) De "Lamontalylo siufonía" en Autóctonas, I a Par. 1920.

(10) V. Estuarcio Núñe\%, Expresionismo en la poesta indigeua del Perú. The Spanish Review. New York, 1930. 
Aún su Epopcia do tropico (Río de Janeiro, 1926), cuya edición restringida es bilingüe, en español y portugués, $\mathrm{y}$ cuya versión literaria fué la obra de Silva Lobato, señala, sus ligamentos con la tendencia impresionista anterior, mas ya Anti-poemas, (Buenos Aires, Sociedad de Publicaciones El Inca, 1927) indica un espírítu totalmente renovado. Su poesía es ganada ahora por una objetividad cada vez más sobria y perfecta que ha definido él mismo. Hablando de los poetas brasileños de la hora, en el prólogo de 9 poetas nuevos del Brasil, Bustamante decía en 1930: "Poesía y nada más. Pura poesía que no es lo mismo que la poesía pura del buen abate Bremond. Nada de retórica ni de preceptos. Libertad o libertinaje. Cuando se trata de una verdadera mujer, lo esencial es que viva. Que viva plenamente. Lo mismo ocurre con la poesía. Por falta de libertad había vivido la pobrecita encerrada entre tantas reglas. Ahora salta libre y hace lo que le da la gana. Que viva. Eso es lo esencial".

Es bastante significativa otra frase suya puesta en las primeras páginas de Anti-poemas: "Las cosas se han cansado de que las movanos yahora quierencontemplarnos, movernos y vivir". La cual equivale ai desarrollar una estética del dinamismo objetivo. Trocado el ángulo de la percepción poética, el paisaje se estiliza cada vez más:

$$
\begin{aligned}
& \text { Los árboles, } \\
& \text { cansados de caminar contra el río, } \\
& \text { se han detenido } \\
& \text { a refrescarse los pies en el agua. }
\end{aligned}
$$

La naturaleza adquiere, descle ahora, en sus poemas, una animación y un activismo inusitados:

(11) De "Acuarela", en Antipocmas, Buenos Aires, 1927. 
Después de estrecharte en sus olas, el mar se ha tendido en la playa todo lleno de tus ansias de tus nervios y de tu carne. (12)

Anti-poemas implica la reacción victoriosa contra el pocma tradicional, el del mero juego retórico, o el de la sensibilidad gastada. Se genera en el libro un voto en contra implícito que denuncia la adocenada literatura anterior. A veces, es verdad, Bustamante desciende al puro cerebralismo, a la ingeniosidad mental que en la charla derrochaba tanto. Juegos éstos de inteligencia con insistente sabor de "greguerias" a lo Gómez de la Serna, que reducen aquí y allá en estas páginas:

La catedral

atormentada de infinito

hunde sus torres

en las nubes

para buscar a Dios

Bibliot(dea"Mistica") "as
"Jorge Puccinelli Converso"

$\mathrm{El}$ órgano tísico

hace gimnasia

respiratoria

- porque siente

que se va a quedar afónico

(de "Mística")

El cielo

apenas es un trapo sucio

que está tendido a secar.

(de "Lluvia urbana")

(12) De "Marina" en Antipoemas, Buenos Aires, 1927. 
Corre el tren

mascando carbones

y bufando premuras y protestas

(de "El tren")

Las nubes

se agarran a las copas de los árboles para que no se las lleve el viento

(de "Nubes")

Para abrigarse del frío de esta altura donde hasta el sol se ha helado

iel monte ha metido su cabeza blanca

en el pesado poncho

de las nubes.

$$
\text { (de "Puna") }
$$

Pero al lado de esta fácil inventiva de la hora estridentista-creación que salía indudablemente del ámbito de la poesía para ingresar en el de la prosa-se encuentra el poema definitivo que con sucarga de poesía intensa y verdadera es de antes y de ahora y basta parasjustificar el libro y para consagrar al poeta:

\section{"Anhelo".}

La campiña

temblorosa de eternidad ante la noche se refresca en el viento y en el río

y perfumada de fragancias ingenuas

espera al que siempre es esperado.

Al que no tiene nombre

ni forma

y para quien son todas las palabras

y las imágenes 
$\mathrm{Y}$ bajo el peso de la sombra, intranquila por saber lo que ella oculta, clava las uñas en su misterio

y sólo encuentra la mirada de unos ojos sin pupilas que callan como la sombra, pero que están como la sombra llenos de la voluptuosa presencia del esperado.

La dramática intensidad de este poema no tiene, creemos, precedente en la literatura peruana. El señala tal vez la plenitud de un poeta capaz de dar una sensación altísima del misterio, de desolada esperanza y de sentimiento cósmico. De nuevo encontramos aquí un brote expresionista en la poesía de Bustamante.

Floración del sentimiento peruanista.

Y llegamos a aquel libro suyo, el último que él escribiera, que condensa su inquietud de los últimos tiempos: Junín (Lima, I930, Imp. La Revista). Ya antes, desde Autóctonas, había ensayado notas indigenistas junto a cantos continentales.

La región a cuyos estímulos naturales se deben estos, poemas, había sido por muchos meses escenario de sus andanzas y recorridos durante el año de 1923 , época en que se le encomendó en ella un cargo oficial. Sus "vivencias", plasmadas literariamente los años siguientes, habían permanecido por mucho tiempo inéditas.

Cuando hubo llegado el momento de sentar raíces en la tierra natal, Bustamante decidió esta edición para la que había alimentado tanta esperanza, y en la cual había puesto tanta emoción, tanta tibieza, en el extranjero, estando la tierra propia lejana.... 


\section{"Los morochucos".}

Cascos duros de piedra, erizados pellejos serranos pulmones de distancia y altura bebedores de vientos y cielos. Oteadores de invisibles caminos, incansables y humildes comedores de ichu que abrevan en el fango y ruedan como galgas hacia abajo para volar como cóndores a las cumbres.

Cual el corcel del llanero y del gaucho vienen de la Conquista, pero anidando en los Andes

se han hecho indios.

Incansables, tenaces y fuertes, invencibles donde el aire en la altura se afila.

Estampas, no poemas, queremos ver nosotros en Junin. Cromos que guardan retazos de paisaje andino para las horas de la nostalgia. Alta poesía, no siempre. Magnífica prosa descriptiva, ante todo. Cuando desacierta no es porque su poesía disuene o desentone, sino porque se torna prosa. No encontró Bustamante, tal vez, la frontera exacta entre el poema y la mera impresión de viajero exquisito. De tal modo juzgamos los que nos detenemos en su último libro, el de la experiencia serrana e indígena, que no trasluce afán de identificarse con el indio o su paisaje, sino que pretende ser únicamente un intento de registrar vividas y muy sinceras impresiones, tan puras, tan lejanas de toda retórica, tan desprovistas de literatura inútil, que los más avisados han descubierto hasta frialdad o 
prosaísmo, ausencia de hechizo verbal. Con más o menos distancia, son aplicables a Iunin, las propias palabras de Bustamante con que perfila la poesía del gran brasileño Ribeiro Couto: "Con finísimo paladar estético, tiene, como él dice, la audacia del mal gusto. Huye de los temas poéticos, quiere la vida tal como se le presenta, con la poesía de lo cotidiano".

No obstante, intercálase en Iunín, que tan acertadamen ilustró con apuntes agilísimos, la gran pintora peruana Julia Codesido, alguna nota impregnada de fina ternura inclígena, con reminiscencia de "yaraví" melgariano y tono distinto que el restante contenido del libro:

"Quenas"

(Blanca de luna la quena

- hila en la noche su cantar)

Palomita de nieve

sin sol,

quien te hiciera

Brosada de amor. Letras

Palomita blanca

como el nevado, como él das sombra

$\mathrm{y}$ viertes luz.

Luz de deseos

a quien te mira, noche de penas

a quien te amó.

EL TRADUC'TOR DE LOS POETAS.

Bustamante es más poeta aún tal vez por su devoción a los poetas y a la cultura que por su propia poesía lograda. 
No solamente lo es en el libro, lo es también en el gesto espiritual y en todo acto de la vida. Y su sensibilidad literaria estuvo más al servicio de interpretar el alma de los demás creadores que dedicada a labrar su obra personal. Era perenne su esfuerzo por ayudar las consagraciones difíciles o estimular las vocaciones verdaderas. Rehuía siempre las oportunidades en que podía suponérsele ansioso del elogio a su obra, pero su actitud era incondicionalmente decidida al juzgar las obras ajenas con largueza, con sinceridad, sin reticencias, acaso con excesiva tolerancia. Cuando ultimábamos el plan de ediciones de la "Biblioteca Perú Actual"-que en una época de clausura universitaria dió el único aliento que acusaba la supervivencia del intelecto en Lima-se trató de lanzar una nómina de los próximos intelectuales que tendrían acogida en ella. "Quiero que estén todos, decía, que no haya exclusiones".

Sus andanzas de diplomático to llevaron al Brasil. Detrás del exquisito fingimiento del protocolo, debía ejercer muy alta sugestión esa mirada ágil, y esa dicción fácil y traviesa que constituían parte de los atractivos personales de Bustamante. Y la comunidach con lōs poetas nuevos y viejos del Brasil se fraguó desde el comienzo de su estadía Muy pronto se entregará de lleno a la tarea de traducirlos, como pocos identificado espiritualmente con ellos. Y Bustamante deviene no el mero y trasportador de imágenes y emociones, sino un auténtico recreador de belleza literaria.

Bustamante compone traduciendo y da su propia y leal versión de los románticos, de los parnasianos, de los simbolistas y de los regionalistas del Brasil, al poco tiempo de alternar con ellos. Sale entonces su libro Poctas brasileros que no es solamente un conjunto de traducciones perfectas, sino que constituye una verdadera antología de la producción del Brasil, desde el romanticismo hasta nuestros días. Ocho años después, como no podía olvidar a los más jóvenes creadores cariocas, con quienes tanta apro- 
ximación personal y literaria había tenido durante su estadía en Río, culmina su labor con otro tomo de traducción: 9 poctas meevos del Brasil (Lima, Imprenta Minerva, 1930). Ribeiro Couto, que es de los poetas traducidos, aquel que más afinidad muestra en su obra con la de Bustamante, decía que el traductor había cumplido el alto papel de difundir la poesía brasileña en todo el mundo hispánico y desde Lima la última vez. Proyección espléndida de su actitud vital de animador y cruzado de la difusión del esfuerzo literario tan aciorde con otros actos suyos de culturizador insigne.

EL PROSADOR MÚl.TIPLE.

Su actividad literaria fué constante y diversa como pocas en el Perú. En la prosa, lo veremos surgir como crítico literario, como cuentista, como autor de prosas poemáticas, como cronista del efímero suceso cotidiano. Ligero y rápida algunas veces, adquiere su prosa en otras oportunidades una pulimentación y solidez tal que rivaliza con la de su contemporáneo Valdelonar. Precisamente con respecto a la obra de este último y al movimiento literario contemporáneo, ha de aparecer en I9I I, uno de sus ensayos críticos más encomiables. Entonces Valdelomar acababa de publicar "La ciudad de los tísicos" con todo su copioso caudal de sugerencias estéticas. $\mathrm{El}$ año es pródigo en actividades literarias: también González Prada ha impreso su libro poético definitivo y Eguren. ha logrado su primer poemario, Simbólicas. El comentario a Valdelomar es una contribución parcial, pero mèdular al enjuiciamiento de la gran obra del "colónida". Pero su ensayo sobre Eguren, publicado en "Balnearios", nos parece la más oportuna fundamentación crítica producida en el Perú, de la obra de un poeta que se iniciaba, así como la nota de consagración definitiva ha de darla, con otro juicio excelente, Enrique Carrillo desde "Colónida", en 
1916. La introducción general que precede al comentario del primer libro egureniano, plantea por primera vez en el Perú las nuevas modalidades de la poesía simbolista imperante. Llegada ella con algún retraso, la generación de Bustamante va a ser la llamada a asimilar mejor esas notas límpidas y novísimas de los poetas franceses de fines del siglo XIX. Antes de ese momento, sólo habíase acogido a los decadentistas o parnasianos. Influjo directo era más notorio de parte de los americanos, sobre todo de los mexicanos premodernistas. Después siguió la decisiva influencia de Rubén, de la cual tampoco podrá prescindir en su primera época el propio Bustamante y Ballivián. Va a ser éste, en ese mentado juicio crítico de Eguren, el que ha de traer al gran público, la explicación del nuevo concepto simbolista de la poesía. A propósito del poeta que tantas resistencias concitaba, Bustamante introdujo finos y razonados argumentos sobre la. nueva visión del mundo que insinuaban los poetas. E incluía larga cita de las postulaciones de Mallarmé.

A Bustamante se debe, sin duda, lo que convendremos en llamar la "recepción" de Eguren. Su tributo a esta obra no ha de quedarallí, en 19II. Allegará, luego, más tarde, en 1924, con motivo del homenaje que Zulen organizó a Eguren, desde el "Boletín Bibliografico de la Universidad" que él dirigía, publicándole una selección de sus poesías, los datos y los recuerdos de las incidencias de la infancia y de la juventud de Eguren que a su juicio habían contribuido más a modelar el espíritu y a preparar la acción de futuro poeta; datos éstos que han iluminado a la crítica para la mejor explicación y ahondamiento en el sentido de la poesía del gran creador peruano.

Su único libro en prosa, La evocadora, lo hemos estudiado al tratar su obra poética. Su carácter poemático, pone a esa prosa dentro de los límites de la poesía más selecta. No obstante, hay en él páginas de aguda penetración justipreciadora, como aquellas que van dedicadas al paisaje y a su 
evolución a través de las épocas literarias y de las sensibilidades artísticas y define con certeza los caracteres del sentimiento de la naturaleza dentro de su momento de angustiosa laxitud d'annunziana.

Como sus cuentos, que a pesar de su propósito, no llegó a coleccionar en libro y en que, alguna vez, destaca la huella de los rubendarianos de Azul,- "El robo", "Maese Sutil", "Arsinoe", "La duda"—andan también desperdigadas en diversos periódicos y revistas de I910 a I920, innumerables crónicas periodísticas ligeras que-ausente en ellas toda intención literaria- él firmaba con el seudónimo "Félix de Ayala".

\section{SEMblanza moral.}

Fué Bustamante casi por imperativo biológico un "independiente". La calidad de su temperamento no le permitió nunca atarse a la severidad de los grupos, en los que tal vez no encontró la necesaria flexibilidad para seguir el ritmo de las épocas con la intensidad que él logró individualmente.

Cuanta pesadumbre causaron necesariamente sus ansias insatisfechas siempre de renovación, en aquellos espíritus estereotipados e inmovilizados culturalmente en una época determinada, que tanto abundan por esta tierra. Bustamante era para ellos, el tornadizo, el "revolucionario", el veleidoso. Para otros, como dice Jorge Basadre, era el hombre en quien se reconocía "una gran permeabilidad para las influencias. A Enrique Bustamante y Ballivián, desertor, está dedicado un poema humorístico de Gibson. Preferible esta receptividad para el sonido de la hora, que la caparazón de elefante de que otros se presumen para no oir sino lo que su juventud oyó, como si lo más bello de la vida no fueran la sorpresa y el azar" El no quiso nunca reparar en lo que esos decían, porque si los hubiera oído o visto no hubiera disfrazado su gesto de desdeñosa ironía que al incomprensivo re- 
galaba. Firme supo quedar siempre con su visión clara y un poco melancólica y algo pesimista de la vida. Recto supo abatir las envidias, las malignidades o las omisiones, sin reprocharlas nunca, porque no gustaba de hablar o de oir decir de sí mismo. De muchos es conocido el caso de un joven pocta peruano que compiló una antología de la nueva poesía americana, incluyendo en la sección Brasil varias traducciones tomadas de Poetas brasileros, sin indicar la fuente ni el verdadero traductor. Bustamante solía ironizar sobre este atentado, cuando alguien lo urgía a comentarlo. Nunca quiso hacer publicidad sobre hecho semejante. Se limitó, en son de discretísima protesta, a colocar en un ejemplar que adquirió de la citada antología, unas minúsculas iniciales de su nombre al lado de cada poema cuya traducción reconocía como suya. Un día nos obsequió el único libro así anotado.

Habría que reclamar aquí-ya que él nunca lo insinuó siquiera-de cierta descleñosa omisión del examen de la obra? total de Bustamante en el "Proceso de la literatura peruana" de Mariátegui (13). Contrastando con detenimiento en muchos poetas intrascendentes que le merecieron párrafo aparte, Mariátegui esquiva la referencia de quien pudo merecer en su crítica eP rango de "suscitador", ya que su posición de "independiente" en que lo sitúa, al lado de Alberto Ureta, excedía de su propósito ideológico.

Cuando bregó literariamente en la revista propia o en el artículo periodístico o en el prólogo cordial, fué su pluma dirigida siempre a abrir el cauce de la comprensión general para la obra ajena. Nunca se arrogó título alguno. El único título que consentía en aceptar era el de haber propiciado la poesía luchador por la obra y conseguido que el nombre de José María Eguren fuera estimado entre las gentes como el de uno de los más altos poetas del Perú

(13) Mariátegui, obra cit. 
Faena dura la de vivir en este país sin ostentar. dinero, sin curvaturas corteses, sin frases solemnes, sin mendaces ofrecimientos: faena árdua que él cumplió sin doblegarse jamás, enfrentando la vida en todos los campos y tambien en el de la discreta actividad industrial de su imprenta de Guadalupe. Desde aquí fué donde en los últimos años, lanzó su "Biblioteca Perú Actual", abierta a la inteligencia del país, para estimular sin el sacrificio del escritor antes obligado a sufragar el gasto de sus ediciones, la producción intelectual del país. A esta obra y a la de ganar la vida, estuvieron consagrados estos últimos años que no dejaron casi margen a su propia tarea literaria. Actitud de recogimiento personal, al mismo tiempo que de estímulo generoso a la juventud para que afrontara la labor cultural.

Signo de tRANSICIÓN.

El signo de transición preside la obra de Bustamante y Ballivián. Más que la envergadura del creador por excelencia, Bustamante adopta la actitud del suscitador de inquietudes. Por algo su actividad en las letras empieza cuando dirige una revista de jutventud ("Contemporáneos"), y termina cuando funda y consolida una editorial de cultura (La Biblioteca y Ediciones Perú-Actual). Sus valores vitales se plasmaron y desenvolvieron en esta tarea de animador. Su poesía misma se explica así: abrir la ruta nueva, haciéndose eco de la última dirección poética, dando siempre la nota actual. Marchaba paralelamente a los tiempos çomo para recordar que el que se queda retrasado muere para el espíritu. Siendo hombre de una generación pasada, la juventud lo buscaba siempre.

No obstante, su actitud no era la de servil e incondicional acatamiento a las audacias juveniles. Dejaba siempre a salvo un original apunte o la discrepancia razonada: nada 
aceptaba "a priori" como no fuera el ímpetu sincero o el respeto por el derecho de pensar.

Nada de lo nuevo promovía su sorpresa: su mente, ávida de novedad, captaba sin dilación el latido del momento. Si en 1909 se había enfrentado al público y a la crítica adversa para introducir a un gran poeta como José María Eguren, que hasta entonces era desdeñado y menospreciado y zaherido con la ironía estulta, en 1935 coincidía con nosotros en precisar la extremada incomprensión para reconocer un carácter trascendente, en la literatura peruana, a la poesía de Emilio Adolfo Westphalen. Si hubiera llegado la oportunidad de la polémica, no hubiera negado su concurso como en 1909: su actitud juvenil era la misma.

Cuando fué la hora de enrumbar definitivamente el modernismo en el Perú, al margen de la dirección individual de Chocano, el fué modernistá de verdad, con derroche de colores y de sonidos. Cuando llegó el momento de propiciar cierto impresionismo continental, él fué de los primeros en explotar el paisaje y la vida americana. Cuando hubo arribado la dislocante travesura estética de la vanguardia de posguerra, también estuvo presentecon sur concreción polémica y juvenil: el anti-poema. Cuando el calor de la tierra nos abrasa con su imperativo telúrico, también es regionalista que exalta al hombre del Ande. En todos los momentos supo estar, con su juventud invívita.

Si no le hubiera tocado vivir esta época de transición que persigue-junto con otras esencias de vida-un nuevo y aún incógnito concepto de la poesía, tal vez podría haber sido el poeta de la obra única y regular, de la obra de genio. Pero fué designio de la jépoca que así no lo fuera y que se ofrendara mejor asimilándose a la cambiante y nerviosa multiplicidad de estos años que son de agonía, usando el léxico de Unamuno. Bustamante fué leal con su tiempo; en su obra supo hacerse siempre eco de su momento. Iniciando una nueva etapa poética-aquella antielocuente y selecta etapa 
del tono menor y del buen gusto que se inicia en I9Io-marca, produciendo él mismo y animando la obra ajena, un lento y penoso proceso de evolución en las icleas y en las creaciones literarias del Perú. Por eso, la obra poética de Bustamante y Ballivián tiene la virtud objetiva de mostrarnos, como en un prisma, el proceso de lo modema poesía peruana.

Estuardo Núñ̃̃z.

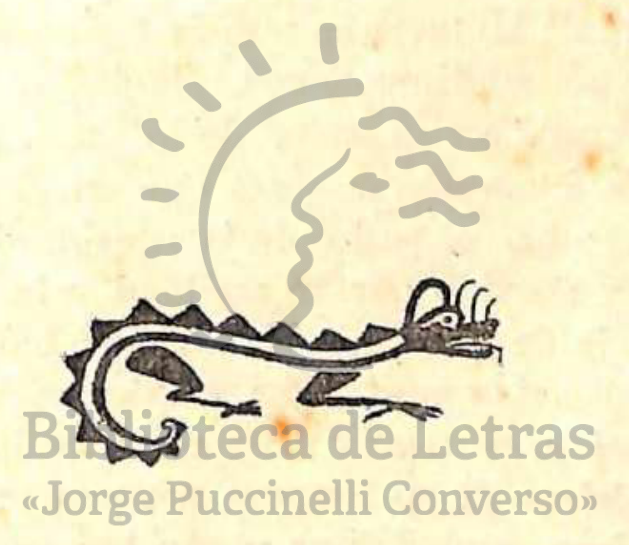

